\title{
Effect of Mefenamic Acid to Acupuncture Therapy on Carrageenan- Induced Inflammatory Pain in the Hind Limb of Rat
}

\author{
Yovita Mercya, Andreanus A. Soemardji, Felesia Fanty \\ Clinical Pharmacology and Toxicology Department \\ School of Pharmacy Bandung Institute of Technology \\ Gedung Yusuf Panigoro Labtek VII \\ Jalan Ganesa no.10 Bandung 40132 Indonesia \\ Email: yovita_farma@yahoo.co.id
}

\begin{abstract}
Nonsteroidal anti-inflammatory drug (NSAID) and acupuncture are treatments for inflammatory pain. The purpose of this study is to see the effectiveness of mefenamic acid, a drug from the class of NSAIDs compared with acupuncture therapy in 24 male Wistar rats that have received intraplantar induced of carrageenan. The experimental animals are divided into six groups: pain control group, mefenamic acid group, before-induction acupuncture group, after-induction acupuncture group, before-induction mefenamic acid-acupuncture combination group, and after-induction mefenamic acid-acupuncture combination. Inflammation and pain assessment with inflammation volume and pain threshold parameters tenderness is done every 60 minutes during 6 hours after induction of carrageenan. The results of animal studies show that the combination of mefenamic acid - acupuncture before induction (inflammation inhibition value of 40.24\%; pain inhibition value $8.95 \%)$ shows a significantly smaller value $(p<0.05)$ in reducing inflammation and increasing the pain threshold compared to single mefenamic acid group (inflammation inhibition value 58.53\%; the pain inhibition value 29.09\%) and single acupuncture therapy before induction (inflammation inhibition value $78.04 \%$; the pain inhibition value 23.07\%). It happens because mefenamic acid inhibits the action of acupuncture as an analgesic. This study concludes that the administration of mefenamic acid degrades the effectiveness of acupuncture therapy in addressing inflammatory pain.
\end{abstract}

Keywords: acupuncture, mefenamic acid, carragenaan, analgesic, antiinflammation 


\title{
Pengaruh Pemberian Asam Mefenamat terhadap Terapi Akupunktur pada Nyeri Radang Karagenan Kaki Tikus
}

\author{
Yovita Mercya, Andreanus A. Soemardji, Felesia Fanty \\ Bagian Farmakologi Toksikologi Klinik \\ Sekolah Farmasi Institut Teknologi Bandung \\ Gedung Yusuf Panigoro Labtek VII \\ Jalan Ganesa no.10 Bandung 40132 Indonesia \\ Email : yovita_farma@yahoo.co.id
}

\begin{abstract}
Abstrak
Obat antiinflamasi non steroid (NSAID) dan akupunktur merupakan terapi untuk mengatasi nyeri radang dengan mekanisme kerja yang berbeda satu dengan yang lainnya. Tujuan penelitian ini adalah untuk melihat pengaruh pemberian asam mefenamat, salah satu obat dari golongan NSAID terhadap akupunktur pada 24 ekor tikus Wistar jantan yang diinduksi karagenan. Hewan uji dibagi ke dalam enam kelompok yaitu kelompok kontrol sakit, kelompok asam mefenamat, kelompok akupunktur sebelum induksi, kelompok akupunktur sesudah induksi, kelompok kombinasi asam mefenamat-akupunktur sebelum induksi, dan kelompok kombinasi asam mefenamat-akupunktur sesudah induksi. Penilaian inflamasi dan nyeri dengan parameter volume radang dan ambang nyeri tekan dilakukan setiap 60 menit selama enam jam setelah induksi karagenan. Hasil penelitian pada hewan coba menunjukkan bahwa kombinasi asam mefenamat-akupunktur sebelum induksi (nilai inhibisi radang 40,24\%; nilai inhibisi nyeri $8,95 \%)$ menunjukkan nilai yang lebih kecil bermakna $(p<0,05)$ dalam menurunkan volume radang dan meningkatkan ambang nyeri tekan dibandingkan terapi tunggal asam mefenamat (nilai inhibisi radang 58,53\%; nilai inhibisi nyeri 29,09\%) dan terapi tunggal akupunktur sebelum induksi (nilai inhibisi radang 78,04\%; nilai inhibisi nyeri 23,07\%). Hal ini disebabkan karena asam mefenamat menghambat kerja akupunktur sebagai analgetika. Simpulan penelitian ini, asam mefenamat berpengaruh menurunkan efektivitas akupunktur dalam mengatasi nyeri radang.
\end{abstract}

Kata kunci: akupunktur, asam mefenamat, karagenan, analgetika, antiinflamasi 


\section{Research Article}

\section{Pendahuluan}

Radang atau inflamasi adalah satu dari respon utama sistem kekebalan tubuh terhadap rangsangan fisik/mekanis, kimia, dan mikroorganisme patogen untuk melindungi jaringan dari penyebaran infeksi yang distimulasi oleh faktor kimia sebagai mediator peradangan. Proses inflamasi juga berpotensi merugikan, antara lain menyebabkan reaksi hipersensitivitas yang mengancam jiwa, kerusakan organ progresif, pembentukan jaringan parut, dan lain-lain. Respon peradangan dapat dikenali dari lima tanda, yaitu calor (panas), rubor (kemerahan), tumor (bengkak), dolor (nyeri), dan fungsio laesa (gangguan fungsi). Lima tanda peradangan ini disebabkan karena terjadi perubahan pada pembuluh darah dan jaringan limfatik di area infeksi. 1,2

Nyeri adalah salah satu gejala inflamasi setelah panas, kemerahan, dan bengkak. Nyeri akibat radang dapat disebabkan adanya peregangan jaringan (akibat edema) sehingga terjadi peningkatan tekanan lokal. Nyeri radang juga disebabkan karena pengeluaran zat kimia atau mediator nyeri (seperti prostaglandin, histamin, bradikinin) yang merangsang reseptor nyeri (nosiseptor) di sekitar radang sehingga menghasilkan impuls nosiseptif. Nyeri merupakan pengalaman subjektif tanpa adanya ukuran objektif, yang mana keluhan pasien adalah indikator utama dari gejala dan intensitasnya. ${ }^{3,4}$

Upaya mengontrol dan mereduksi nyeri radang dapat dilakukan baik secara farmakologis maupun secara non farmakologis. Terapi farmakologis yang sering digunakan adalah obat antiinflamasi nonsteroid (NSAID). Mekanisme kerja dari obat golongan NSAID adalah menghambat prostaglandin melalui penghambatan enzim siklooksigenase (COX) yang akan menyebabkan terhambatnya sintesis prostaglandin. Prostaglandin adalah salah satu faktor kimia yang dihasilkan dari adanya proses inflamasi yang berperan sebagai mediator peradangan dan nyeri. Obat yang termasuk dalam golongan ini antara lain aspirin, asam mefenamat, ibuprofen, methampiron, natrium diklofenak, piroksikam dan beberapa preparat lainnya. ${ }^{5}$

Terapi nonfarmakologi yang sering digunakan sebagai terapi alternatif untuk mengobati nyeri adalah akupunktur. Akupunktur adalah pengobatan menggunakan penusukan jarum pada beberapa titik saraf manusia. Akupunktur bekerja melalui mekanisme secara lokal, segmental, dan sentral. Penusukan akupunktur akan meningkatkan sekresi mediator peradangan yang akan menyebabkan dihasilkannya sinyal pada nosiseptor. Selanjutnya serabut somatik aferen membawa sinyal dari penusukan jarum ini ke medula spinalis dan mengaktifkan hipofisishipotalamus yang akan melepaskan opioid endogen ke pembuluh darah dan cairan 


\section{Research Article}

serebrospinal. Hal ini berakibat pada meningkatnya analgesia fisiologis dan homeostasis berbagai macam sistem termasuk sistem imun. ${ }^{6}$

Dalam beberapa kasus, kedua terapi ini seringkali dikombinasikan dengan harapan menghasilkan efek analgetik antiinflamasi yang lebih baik, sehingga perlu dikaji efektivitas kedua terapi jika digunakan bersamaan. Beberapa penelitian yang berkaitan dengan penelitian ini dilakukan oleh Rivas Vilchis pada tahun 2009 dalam penelitiannya yang berjudul "The effect of acupuncture on leukocyte level in peripheral blood is modified by aspirin", yang mana pada penelitian ini disimpulkan bahwa pemberian aspirin yang merupakan obat dari golongan NSAID dapat menurunkan kadar leukosit pada pasien yang diterapi akupunktur ${ }^{13}$. Pada tahun 2013, Ming Tsang Wu dalam penelitiannya yang berjudul "Interaction of acupuncture and electroacupuncture on pharmacokinetics of aspirin and the effect of brain blood flow in rat" menyimpulkan bahwa terjadi interaksi farmakokinetik pada pemberian aspirin dan akupunktur, serta terjadi perubahan aliran darah ke otak pada percobaan menggunakan tikus. ${ }^{15}$

Berdasarkan latar belakang di atas maka dilakukan penelitian dengan tujuan untuk mengkaji pengaruh pemberian NSAID terhadap terapi akupunktur pada nyeri radang. Penelitian diawali dengan pengambilan data untuk mengkaji efektivitas terapi NSAID dan akupunktur GI pada pasien dengan keluhan nyeri radang menggunakan angket yang berisi skor Visual Analogue Rating Scale (VAS) di Klinik Akupunktur Kompleks Sukamenak Indah Blok $\mathrm{N}$ no. 7 dan di UPT Bumi Medika Ganesa ITB di Jalan Gelap Nyawang no. 2, Bandung. Responden terdiri dari 44 pasien yang sedang menjalani terapi akupunktur GI dan pernah menggunakan NSAID sebelumnya. Berdasarkan angket tersebut diperoleh hasil bahwa asam mefenamat merupakan obat yang seringkali digunakan untuk pengobatan nyeri radang. Hasil kajian klinis ini kemudian digunakan untuk mendesain penelitian eksperimental pengaruh pemberian asam mefenamat terhadap terapi akupunktur dilakukan pada tikus Wistar jantan.

\section{Metode}

Desain penelitian ini adalah eksperimental laboratorik, komparatif dengan menggunakan Rancangan Acak Kelompok (RAK). Penelitian dilakukan di Laboratorium Hewan Farmakologi Sekolah Farmasi ITB pada bulan Februari 2016.

Alat yang digunakan dalam penelitian ini adalah spuit injeksi suplantar dan peroral $1 \mathrm{ml}$ \& $3 \mathrm{ml}$ (merk Terumo), pengukur waktu, jarum akupuntur dengan ukuran \#0.25 x 25 (merk Huanqiu), dolorimeter yang dimodifikasi, pletismometer, plester, gunting, kandang tikus. Bahan 


\section{Research Article}

uji adalah larutan karagenan $1 \% \mathrm{~b} / \mathrm{v}$ (dibuat dari serbuk karagenan lambda yang diperoleh dari Sigma Aldrich), larutan suspensi asam mefenamat 0,5\% b/v, suspensi PGA 3\%. Hewan yang digunakan dalam penelitian ini adalah tikus Wistar jantan dengan berat badan 180-200 gram, berusia 2-3 bulan, dan memiliki aktivitas normal yang diperoleh dari Laboratorium Hewan Sekolah Farmasi, Institut Teknologi Bandung berjumlah 24 ekor dan dibagi ke dalam enam kelompok. Hal ini memenuhi Rumus Federer, yaitu:

$$
(n-1)(t-1) \geq 15
$$

\section{Keterangan}

$\mathrm{n}=$ jumlah hewan percobaan per kelompok

$\mathrm{t}=$ jumlah kelompok

Penelitian ini telah mendapatkan persetujuan dari Komisi Etik Penggunaan Hewan Percobaan Institut Teknologi Bandung (No. 05/KEPHP-ITB/02-2016) dengan memperhatikan prinsip 3R, yaitu replacement, reduction, and refinement.

Sebelum digunakan, hewan coba dikontrol kesehatannya dan diadaptasikan selama tujuh hari dan sebelum hari percobaan, hewan coba dipuasakan kurang lebih 12 jam dengan air minum ad libitum. Hewan coba nyeri radang dibuat dengan induksi suspensi karagenan 1\% sebanyak $0,1 \mathrm{~mL}$ secara intraplantar pada telapak kaki kiri belakang. Setiap hewan uji dikelompokkan menjadi enam kelompok secara acak dengan jumlah masing-masing kelompok empat ekor yaitu kelompok kontrol sakit, yang diberi pembawa suspensi PGA 3\%; kelompok pembanding, yang diberi suspensi asam mefenamat dosis $50 \mathrm{mg} / \mathrm{kgBB}$ tikus; kelompok akupunktur sebelum induksi, yang diberi suspensi PGA 3\% dan terapi akupunktur 30 menit sebelum induksi karagenan; kelompok akupunktur sesudah induksi, yang diberi suspensi PGA 3\% dan terapi akupunktur 30 menit sesudah induksi karagenan; kelompok kombinasi akupunktur sebelum induksi-asam mefenamat, yang diberi suspensi asam mefenamat dosis $50 \mathrm{mg} / \mathrm{kgBB}$ tikus dan terapi akupunktur 30 menit sebelum induksi karagenan; dan kelompok kombinasi akupunktur sesudah induksi-asam mefenamat, yang diberi suspensi asam mefenamat dosis $50 \mathrm{mg} / \mathrm{kgBB}$ tikus dan terapi akupunktur 30 menit sesudah induksi karagenan.

Parameter pengamatan pada penelitian ini adalah volume radang dan ambang nyeri tekan kaki tikus. Pengukuran volume radang kaki dilakukan untuk menentukan persentase peningkatan radang dan persentase inhibisi radang dari terapi yang diberikan. Pengukuran ini dilakukan dengan menggunakan alat plestimometer berdasarkan hukum Archimedes. Pengukuran ambang nyeri tekan dilakukan untuk menentukan persentase penurunan ambang 


\section{Research Article}

nyeri tekan dan persentase inhibisi nyeri dari terapi yang diberikan. Pengukuran dilakukan dengan menggunakan alat dolorimeter yaitu melalui penekanan pada kaki dengan nyeri radang. Pengamatan volume radang dan ambang nyeri tekan dilakukan sebelum induksi dan setiap 60 menit selama enam jam setelah pemberian induksi.

Persentase peningkatan radang dan persentase penurunan ambang nyeri pada tiap waktu pengamatan dapat dihitung dengan rumus:

$$
\begin{aligned}
& \% \text { peningkatan radang }=\frac{(V t-V o)}{V o} \times 100 \% \\
& \% \text { penurunan ambang nyeri }=\frac{-(P t-P o)}{P o} \times 100 \%
\end{aligned}
$$

dengan : $\quad V_{0}=$ Volume telapak kaki awal sebelum diinduksi

$\mathrm{Vt}=$ Volume telapak kaki pada tiap waktu pengamatan

Po $=$ Ambang nyeri tekan awal sebelum diinduksi

$\mathrm{Pt}=$ Ambang nyeri tekan pada tiap waktu pengamatan

Potensi terapi antiradang dan antinyeri dihitung berdasarkan persentase inhibisi radang dan persentase inhibisi nyeri dengan rumus :

$$
\begin{aligned}
& \% \text { inhibisi radang }=100 \%-\left(\frac{\text { total AUC perlakuan }}{\text { total AUC kontrol }} \times 100 \%\right) \\
& \% \text { inhibisi nyeri }=-\left[100 \%-\left(\frac{\text { total AUC perlakuan }}{\text { total AUC kontrol }} \times 100 \%\right)\right]
\end{aligned}
$$

Total Area Under Curve (AUC) adalah jumlah AUC tiap waktu pengamatan. AUC tiap waktu pengamatan dapat dihitung dengan rumus:

$$
A U C=\frac{X 2-X 1}{2} x \Delta t
$$

dengan $\mathrm{X} 1=$ Volume radang awal / Ambang nyeri tekan awal

$\mathrm{X} 2=$ Volume radang akhir/ Ambang nyeri tekan akhir

$\Delta \mathrm{t}=$ Selisih waktu

Pengukuran ambang nyeri tekan dilakukan dengan alat dolorimeter yang dimodifikasi. Alat yang digunakan untuk membuat dolorimeter adalah spuit epidural (merk Perifix), lem plastik, kertas skala, karet, dolorimeter klinis dan timbangan elektrik. Dolorimeter dibuat 


\section{Research Article}

dengan cara menutup bagian lubang jarum spuit epidural dengan menggunakan lem plastik dan menempelkan kertas skala pada bagian spuit barrelnya. Pada ujung plunge spuit ditempelkan bahan yang terbuat dari karet dengan ukuran diameter $1 \mathrm{~cm}$. Dolorimeter ini kemudian dikalibrasi dengan dolorimeter klinis dan timbangan elektrik sehingga dapat digunakan sebagai parameter nilai ambang nyeri dalam satuan kg. Pengukuran dilakukan dengan menekan ujung plunge pada radang kaki tikus sampai batas kertas skala saat tikus mencicit dan dikalibrasi dengan menekan ulang pada timbangan digital dalam satuan gram yang kemudian diubah dalam satuan $\mathrm{kg}$.

Penusukan jarum pada hewan uji yang mendapatkan akupunktur dilakukan setelah tindakan aseptik di titik akupunktur CV 12 pada bagian tengah perut yang merupakan sistem homeostatis utama selama 20 menit. Setelah itu, tikus difiksasi dengan menggunakan plester secara melingkar pada bagian perut yang diberi penusukan untuk memastikan jarum berada pada posisi yang tepat.

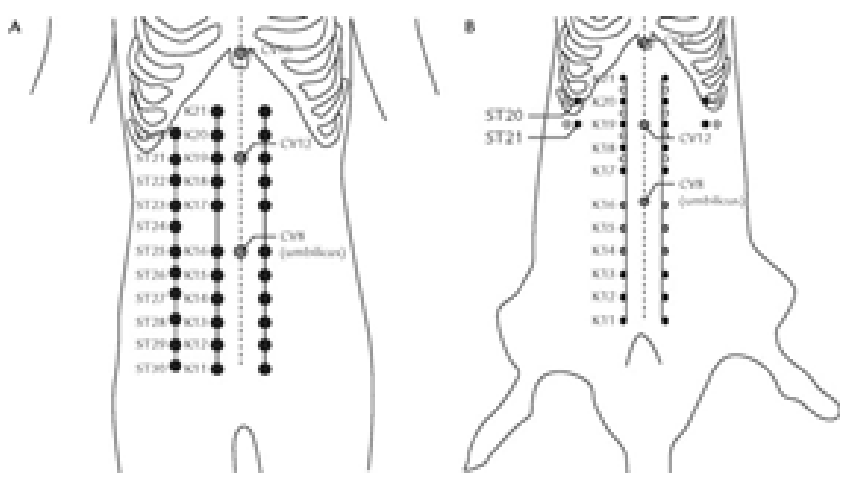

\section{Gambar 1 Perbandingan Titik Akupunktur pada Manusia dan Tikus Percobaan}

Semua data diolah dalam bentuk rerata \pm standar deviasi. Perbandingan data antar kelompok dianalisis menggunakan analisis variasi (Anova) satu arah dengan Least Significant Difference (LSD), nilai $\mathrm{p}<0,05$ menunjukkan perbedaan secara bermakna dan nilai $\mathrm{p}>0,05$ menunjukkan perbedaan tidak bermakna.

\section{Hasil}

Hasil pengukuran volume radang dan ambang nyeri tekan yang kemudian diolah sehingga dihasilkan nilai persentase peningkatan radang dan persentase penurunan radang dapat dilihat pada Tabel 1 dan Tabel 2. 
Tabel 1 Rerata Volume Radang dan Persentase Peningkatan Radang Karagenan Kaki Tikus pada Berbagai Kelompok Perlakuan di Setiap Waktu Pengamatan

\begin{tabular}{|c|c|c|c|c|c|c|c|}
\hline \multirow{2}{*}{ Kelompok } & \multicolumn{7}{|c|}{ Volume radang (Persen Peningkatan Radang) pada waktu pengamatan } \\
\hline & T0 & T1 & $\mathrm{T} 2$ & T3 & $\mathrm{T} 4$ & T5 & T6 \\
\hline \multirow{2}{*}{ Kontrol Sakit } & $\begin{array}{l}0,0340 \pm \\
0,00115\end{array}$ & $\begin{array}{l}0,0558 \pm \\
0,00096\end{array}$ & $\begin{array}{l}0,0568 \pm \\
0,00126\end{array}$ & $\begin{array}{c}0,0583 \pm \\
0,0005\end{array}$ & $\begin{array}{c}0,0588 \pm \\
0,00096\end{array}$ & $\begin{array}{c}0,0580 \pm \\
0,00082\end{array}$ & $\begin{array}{c}0,0545 \pm \\
0,00129 \\
\end{array}$ \\
\hline & $(0 \%)$ & $\begin{array}{c}(64,09 \% \pm \\
5,41)\end{array}$ & $\begin{array}{c}(66,99 \% \pm \\
4,15)\end{array}$ & $\begin{array}{c}(71,45 \% \pm \\
5,10)\end{array}$ & $\begin{array}{c}(72,92 \% \pm \\
5,67)\end{array}$ & $\begin{array}{c}(70,69 \% \pm \\
4,43)\end{array}$ & $\begin{array}{c}(60,43 \% \pm \\
6,69)\end{array}$ \\
\hline \multirow{2}{*}{$\begin{array}{l}\text { Asam mefenamat } \\
50 \mathrm{mg} / \mathrm{kgBB} \text { tikus }\end{array}$} & $\begin{array}{l}0,0350 \pm \\
0,00082\end{array}$ & $\begin{array}{c}0,0450 \pm \\
0,00171\end{array}$ & $\begin{array}{l}0,0470 \pm \\
0,00320\end{array}$ & $\begin{array}{c}0,0470 \pm \\
0,00189\end{array}$ & $\begin{array}{c}0,0460 \pm \\
0,00216\end{array}$ & $\begin{array}{c}0,0450 \pm \\
0,00082\end{array}$ & $\begin{array}{c}0,0440 \pm \\
0,00289\end{array}$ \\
\hline & $(0 \%)$ & $\begin{array}{c}(27,92 \% \pm \\
6,28)\end{array}$ & $\begin{array}{c}(34,82 \% \pm \\
11,42)\end{array}$ & $\begin{array}{c}(35,11 \% \pm \\
7,97)\end{array}$ & $\begin{array}{c}(31,40 \% \pm \\
4,30)\end{array}$ & $\begin{array}{c}(28,64 \% \pm \\
4,57)\end{array}$ & $\begin{array}{c}(24,27 \% \pm \\
7,52)\end{array}$ \\
\hline \multirow{2}{*}{$\begin{array}{c}\text { Akupunktur } \\
\text { Sebelum Induksi }\end{array}$} & $\begin{array}{c}0,0355 \pm \\
0,0013 \\
\end{array}$ & $\begin{array}{c}0,0405 \pm \\
0,0021 \\
\end{array}$ & $\begin{array}{c}0,0460 \pm \\
0,0022\end{array}$ & $\begin{array}{c}0,0450 \pm \\
0,0018\end{array}$ & $\begin{array}{c}0,0425 \pm \\
0,0035\end{array}$ & $\begin{array}{c}0,0407 \pm \\
0,0038\end{array}$ & $\begin{array}{c}0,0400 \pm \\
0,0036\end{array}$ \\
\hline & $(0 \%)$ & $\begin{array}{c}(14,08 \% \pm \\
4,00)\end{array}$ & $\begin{array}{c}(29,70 \% \pm \\
7,7) \mathrm{b}\end{array}$ & $\begin{array}{c}(26,90 \% \pm \\
7,60151)\end{array}$ & $\begin{array}{c}(19,80 \% \pm \\
10,38)\end{array}$ & $\begin{array}{c}(14,90 \% \pm \\
11,52)\end{array}$ & $\begin{array}{c}(12,85 \% \pm \\
11,93)\end{array}$ \\
\hline \multirow{2}{*}{$\begin{array}{c}\text { Akupuntur } \\
\text { Sesudah Induksi }\end{array}$} & $\begin{array}{c}0,0355 \pm \\
0,001\end{array}$ & $\begin{array}{c}0,0558 \pm \\
0,0022\end{array}$ & $\begin{array}{c}0,0582 \pm \\
0,0005\end{array}$ & $\begin{array}{c}0,0602 \pm \\
0,0022\end{array}$ & $\begin{array}{c}0,0592 \pm \\
0,0017\end{array}$ & $\begin{array}{c}0,0585 \pm \\
0,0025\end{array}$ & $\begin{array}{c}0,0567 \pm \\
0,0013\end{array}$ \\
\hline & $(0 \%)$ & $\begin{array}{l}(57,16 \% \pm \\
8,38) \mathrm{a}\end{array}$ & $\begin{array}{c}(64,18 \% \pm \\
5,13) \mathrm{a}\end{array}$ & $\begin{array}{c}(69,71 \% \pm \\
3,58) \mathrm{a}\end{array}$ & $\begin{array}{c}(67,01 \% \pm \\
6,99) \mathrm{a}\end{array}$ & $\begin{array}{c}(64,86 \% \pm \\
7,98) \mathrm{a}\end{array}$ & $\begin{array}{c}(59,94 \% \pm \\
5,30) \mathrm{a}\end{array}$ \\
\hline \multirow{2}{*}{$\begin{array}{c}\text { Akupunktur } \\
\text { Sebelum Induksi + } \\
\text { Asam Mefenamat }\end{array}$} & $\begin{array}{c}0,0360 \pm \\
0,0008\end{array}$ & $\begin{array}{c}0,0472 \pm \\
0,0015 \\
\end{array}$ & $\begin{array}{c}0,0520 \pm \\
0,0021\end{array}$ & $\begin{array}{c}0,0537 \pm \\
0,0015 \\
\end{array}$ & $\begin{array}{c}0,0527 \pm \\
0,0021 \\
\end{array}$ & $\begin{array}{c}0,0502 \pm \\
0,0022 \\
\end{array}$ & $\begin{array}{c}0,0482 \pm \\
0,0019\end{array}$ \\
\hline & $(0 \%)$ & $\begin{array}{c}(31,26 \% \pm \\
3,56) \mathrm{b}\end{array}$ & $\begin{array}{c}(44,46 \% \pm \\
5,66)\end{array}$ & $\begin{array}{c}(49,30 \% \pm \\
2,40)\end{array}$ & $\begin{array}{c}(46,52 \% \pm \\
4,60)\end{array}$ & $\begin{array}{c}(39,57 \% \pm \\
5,14)\end{array}$ & $\begin{array}{c}(34,05 \% \pm \\
5,44)\end{array}$ \\
\hline \multirow{2}{*}{$\begin{array}{c}\text { Akupuntur } \\
\text { Sesudah Induksi + } \\
\text { Asam Mefenamat }\end{array}$} & $\begin{array}{c}0,0348 \pm \\
0,0009\end{array}$ & $\begin{array}{c}0,0515 \pm \\
0,0024\end{array}$ & $\begin{array}{c}0,0530 \pm \\
0,0014\end{array}$ & $\begin{array}{c}0,0523 \pm \\
0,0017\end{array}$ & $\begin{array}{c}0,0520 \pm \\
0,0014\end{array}$ & $\begin{array}{c}0,0497 \pm \\
0,0017\end{array}$ & $\begin{array}{c}0,0472 \pm \\
0,0021\end{array}$ \\
\hline & $(0 \%)$ & $\begin{array}{c}(48,25 \% \pm \\
7,28)\end{array}$ & $\begin{array}{c}(52,64 \% \pm \\
7,16)\end{array}$ & $\begin{array}{c}(50,50 \% \pm \\
8,03)\end{array}$ & $\begin{array}{c}(49,78 \% \pm \\
7,61)\end{array}$ & $\begin{array}{c}(43,31 \% \pm \\
8,09)\end{array}$ & $\begin{array}{c}(36,00 \% \pm \\
5,77)\end{array}$ \\
\hline
\end{tabular}

Keterangan :

Pengamatan dilakukan setiap 60 menit selama enam jam setelah induksi karagenan,

Nilai dalam tanda kurung adalah persentase peningkatan radang pada tiap waktu pengamatan,

$\mathrm{a}=$ tidak berbeda bermakna dengan kelompok kontrol sakit dengan $\mathrm{p}>0,05$

$\mathrm{b}=$ tidak berbeda bermakna dengan kelompok pembanding asam mefenamat dengan $\mathrm{p}>0,05$

$\mathrm{n}=4$, rataan (dalam satuan $\mathrm{mL}$ ) \pm standar deviasi 
Tabel 2 Rerata Ambang Nyeri Tekan dan Persentase Penurunan Ambang Nyeri Radang Karagenan Kaki Tikus pada Berbagai Kelompok Perlakuan di Setiap Waktu Pengamatan

\begin{tabular}{|c|c|c|c|c|c|c|c|}
\hline \multirow{2}{*}{ Kelompok } & \multicolumn{7}{|c|}{ Nilai ambang nyeri tekan (Persen Penurunan Ambang Nyeri) pada waktu pengamatan } \\
\hline & T0 & $\mathrm{T} 1$ & $\mathrm{~T} 2$ & $\mathrm{~T} 3$ & T4 & T5 & T6 \\
\hline \multirow{2}{*}{ Kontrol Sakit } & $\begin{array}{c}2,150 \pm \\
0,208\end{array}$ & $\begin{array}{c}1,512 \pm \\
0,184\end{array}$ & $\begin{array}{c}1,550 \pm \\
0,129\end{array}$ & $\begin{array}{c}1,587 \pm \\
0,062\end{array}$ & $\begin{array}{c}1,537 \pm \\
0,188\end{array}$ & $\begin{array}{c}1,575 \pm \\
0,193\end{array}$ & $\begin{array}{l}1,662 \pm \\
0,125\end{array}$ \\
\hline & $(0 \%)$ & $\begin{array}{c}(29,40 \% \pm \\
8,33)\end{array}$ & $\begin{array}{c}(27,53 \% \pm \\
7,59) \mathrm{b}\end{array}$ & $\begin{array}{c}(25,79 \% \pm \\
5,29) \mathrm{b}\end{array}$ & $\begin{array}{c}(27,78 \% \pm \\
12,12)\end{array}$ & $\begin{array}{c}(25,63 \% \pm \\
15,56)\end{array}$ & $\begin{array}{c}(21,70 \% \pm \\
13,39)\end{array}$ \\
\hline \multirow{2}{*}{$\begin{array}{l}\text { Asam mefenamat } \\
50 \mathrm{mg} / \mathrm{kgBB} \text { tikus }\end{array}$} & $\begin{array}{c}2,125 \pm \\
0,125\end{array}$ & $\begin{array}{c}2,100 \pm \\
0,177\end{array}$ & $\begin{array}{l}1,975 \pm \\
0,095\end{array}$ & $\begin{array}{l}1,925 \pm \\
0,095\end{array}$ & $\begin{array}{c}1,887 \pm \\
0,103\end{array}$ & $\begin{array}{l}1,925 \pm \\
0,095\end{array}$ & $\begin{array}{l}1,925 \pm \\
0,095\end{array}$ \\
\hline & $(0 \%)$ & $\begin{array}{c}(0,73 \% \pm \\
12,46) \mathrm{a}\end{array}$ & $\begin{array}{c}(7,00 \% \pm \\
2,47) \mathrm{a}\end{array}$ & $\begin{array}{c}(9,33 \% \pm \\
3,94) \mathrm{a}\end{array}$ & $\begin{array}{c}(11,15 \% \pm \\
3,29) \mathrm{a}\end{array}$ & $\begin{array}{c}9,33 \% \pm \\
3,94\end{array}$ & $\begin{array}{c}(9,07 \% \pm \\
8,45)\end{array}$ \\
\hline \multirow{2}{*}{$\begin{array}{c}\text { Akupunktur } \\
\text { Sebelum Induksi }\end{array}$} & $\begin{array}{c}2,250 \pm \\
0,129\end{array}$ & $\begin{array}{c}2,200 \pm \\
0,355\end{array}$ & $\begin{array}{c}1,812 \pm \\
0,131\end{array}$ & $\begin{array}{l}1,725 \pm \\
0,095\end{array}$ & $\begin{array}{l}1,725 \pm \\
0,206\end{array}$ & $\begin{array}{c}1,837 \pm \\
0,197\end{array}$ & $\begin{array}{c}1,975 \pm \\
0,210\end{array}$ \\
\hline & $(0 \%)$ & $\begin{array}{c}(1,91 \% \pm \\
17,20) \mathrm{a}\end{array}$ & $\begin{array}{c}(19,40 \% \pm \\
4,51) \mathrm{bc}\end{array}$ & $\begin{array}{c}(23,02 \% \pm \\
7,84) \mathrm{b}\end{array}$ & $\begin{array}{c}(23,08 \% \pm \\
10,41) \mathrm{a}\end{array}$ & $\begin{array}{c}(18,26 \% \pm \\
8,56)\end{array}$ & $\begin{array}{c}(11,91 \% \pm \\
11,24)\end{array}$ \\
\hline \multirow{2}{*}{$\begin{array}{l}\text { Akupuntur Sesudah } \\
\text { Induksi }\end{array}$} & $\begin{array}{l}2,187 \\
0,265\end{array}$ & $\begin{array}{c}1,500 \pm \\
0,000\end{array}$ & $\begin{array}{c}1,500 \pm \\
0,163\end{array}$ & $\begin{array}{c}1,625 \pm \\
0,287\end{array}$ & $\begin{array}{c}1,700 \pm \\
0,081\end{array}$ & $\begin{array}{c}2,025 \pm \\
0,330\end{array}$ & $\begin{array}{c}2,075 \pm \\
0,206\end{array}$ \\
\hline & $(0 \%)$ & $\begin{array}{c}(30,62 \% \pm \\
8,87) \mathrm{b}\end{array}$ & $\begin{array}{c}(31,24 \% \pm \\
4,20) \mathrm{b}\end{array}$ & $\begin{array}{c}(25,87 \% \pm \\
7,16) \mathrm{b}\end{array}$ & $\begin{array}{c}(21,22 \% \pm \\
11,97)\end{array}$ & $\begin{array}{c}(6,33 \% \pm \\
19,26) \mathrm{a}\end{array}$ & $\begin{array}{c}(4,54 \% \pm \\
10,45)\end{array}$ \\
\hline \multirow{2}{*}{$\begin{array}{c}\text { Akupunktur } \\
\text { Sebelum Induksi + } \\
\text { Asam Mefenamat }\end{array}$} & $\begin{array}{l}2,125 \\
0,287\end{array}$ & $\begin{array}{c}1,787 \pm \\
0,047\end{array}$ & $\begin{array}{c}1,600 \pm \\
0,081\end{array}$ & $\begin{array}{c}1,587 \pm \\
0,062\end{array}$ & $\begin{array}{l}1,712 \pm \\
0,165\end{array}$ & $\begin{array}{c}1,700 \pm \\
0,091\end{array}$ & $\begin{array}{l}1,737 \pm \\
0,075\end{array}$ \\
\hline & $(0 \%)$ & $\begin{array}{c}(14,77 \% \pm \\
11,12) \mathrm{a}\end{array}$ & $\begin{array}{c}(22,42 \% \pm \\
11,50) \mathrm{b}\end{array}$ & $\begin{array}{c}(24,46 \% \pm \\
8,57) \mathrm{b}\end{array}$ & $\begin{array}{c}(19,01 \% \pm \\
5,86)\end{array}$ & $\begin{array}{c}(19,17 \% \pm \\
9,14)\end{array}$ & $\begin{array}{c}(17,20 \% \pm \\
11,02)\end{array}$ \\
\hline \multirow{2}{*}{$\begin{array}{l}\text { Akupuntur Sesudah } \\
\text { Induksi + Asam } \\
\text { Mefenamat }\end{array}$} & $\begin{array}{l}2,225 \\
0,275 \\
\end{array}$ & $\begin{array}{c}1,625 \pm \\
0,206\end{array}$ & $\begin{array}{c}1,700 \pm \\
0,163\end{array}$ & $\begin{array}{c}1,550 \pm \\
0,057\end{array}$ & $\begin{array}{c}1,675 \pm \\
0,125\end{array}$ & $\begin{array}{c}1,650 \pm \\
0,129\end{array}$ & $\begin{array}{c}1,825 \pm \\
0,236\end{array}$ \\
\hline & $(0 \%)$ & $\begin{array}{c}(26,85 \% \pm \\
5,18) \mathrm{b}\end{array}$ & $\begin{array}{c}(22,98 \% \pm \\
9,53) \mathrm{b}\end{array}$ & $\begin{array}{c}(29,59 \% \pm \\
8,37) \mathrm{b}\end{array}$ & $\begin{array}{c}(23,45 \% \pm \\
14,38)\end{array}$ & $\begin{array}{c}(24,96 \% \pm \\
11,20) \mathrm{c}\end{array}$ & $\begin{array}{c}(16,25 \% \pm \\
19,87)\end{array}$ \\
\hline
\end{tabular}

Keterangan :

Pengamatan dilakukan setiap 60 menit selama enam jam setelah induksi karagenan,

Nilai dalam tanda kurung adalah persentase penurunan ambang nyeri pada tiap waktu pengamatan, $\mathrm{a}=$ berbeda signifikan dengan kontrol sakit dengan $\mathrm{p}<0,05$

$\mathrm{b}=$ berbeda signifikan dengan pembanding asam mefenamat dengan $\mathrm{p}<0,05$

$\mathrm{c}=$ berbeda signifikan dengan akupunktur sesudah induksi dengan $\mathrm{p}<0,05$

$\mathrm{n}=4$, rataan (dalam satuan $\mathrm{kg}$ ) \pm standar deviasi

Hasil uji statistic Levene pada data awal untuk mengetahui homogenitas data volume radang dan ambang nyeri tekan awal pada radang karagenan kaki tikus, menghasilkan $\mathrm{F}$ hitung 1,036 dan 1,509 dengan $\mathrm{p}=0,430$ dan $0,239(\mathrm{p} \geq 0,05)$, hal ini menunjukkan bahwa data volume radang awal dan ambang nyeri awal tiap kelompok perlakuan memiliki varian yang homogen.

Pada kelompok kontrol sakit dilakukan analisis hubungan volume radang dan ambang nyeri tekan pada radang karagenan kaki tikus dengan menggunakan data persentase peningkatan radang dan penurunan ambang nyeri seperti yang terlihat pada Tabel 1 dan Tabel 2 pada sebelum radang maksimal (Gambar 2) dan sesudah radang maksimal (Gambar 3). 


\section{Research Article}

Koefisien determinasi $\left(\mathrm{R}^{2}\right)$ sebelum radang maksimal (pada T1 sampai T3) adalah -0,979, sedangkan koefisien determinasi $\left(\mathrm{R}^{2}\right)$ sesudah radang maksimal (pada $\mathrm{T} 4$ sampai $\mathrm{T} 6$ ) adalah 0,965 yang berarti hubungan bersifat berbanding lurus dan mendekati sempurna.

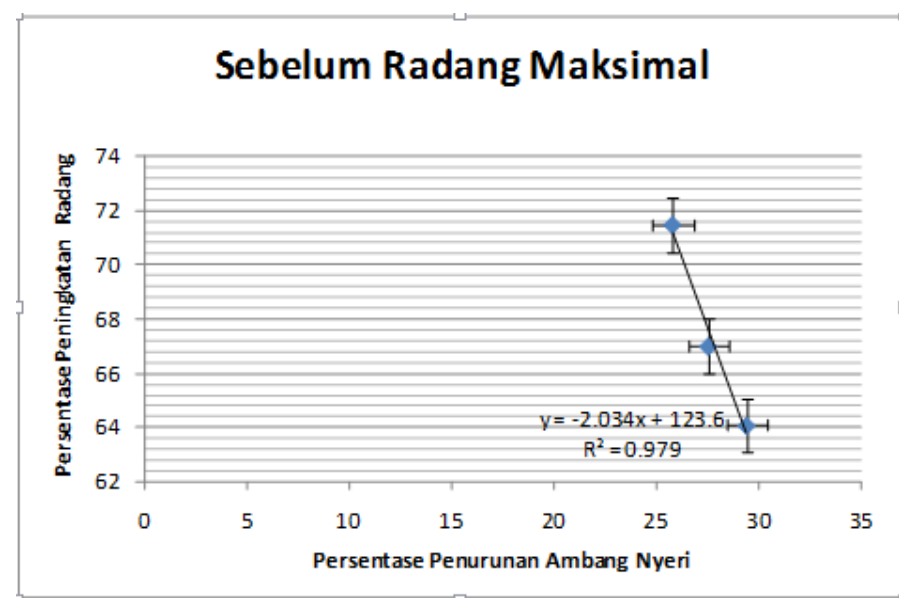

Gambar 2 Grafik Hubungan Persentase Peningkatan Radang dan Penurunan Ambang Nyeri Sebelum Radang Maksimal pada Kelompok Kontrol Sakit

Keterangan: Grafik ini adalah hasil analisis regresi untuk mengetahui hubungan persentase penurunan ambang nyeri (x) dengan persentase peningkatan radang (y) sebelum kelompok kontrol sakit mengalami radang maksimal sehingga diperoleh persamaan matematika $y=-2,034 x+123,6$ dan koefisien determinasi $\left(R^{2}\right)=0,979$

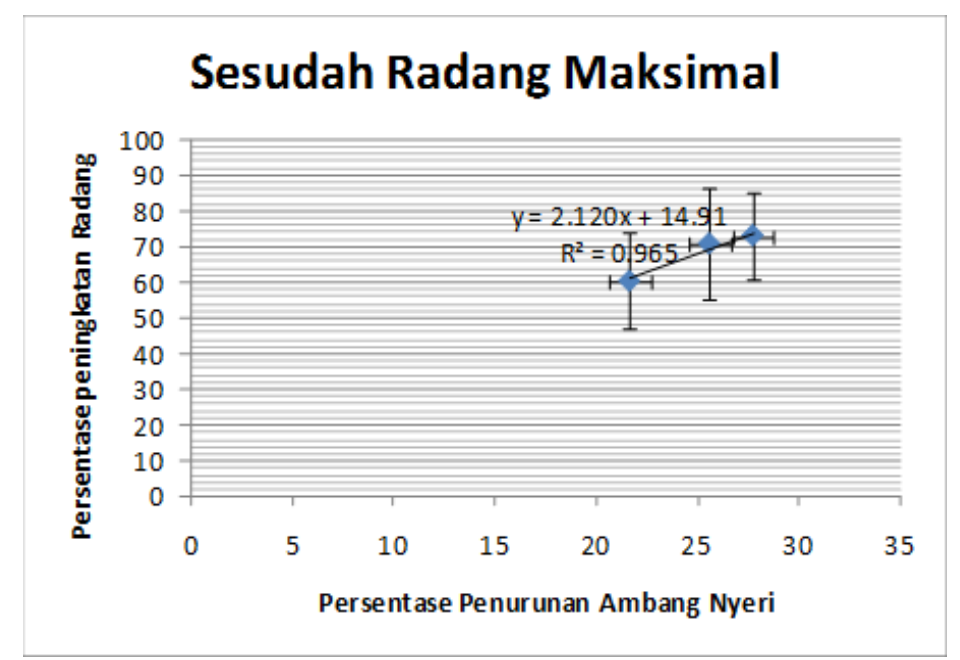

Gambar 3 Grafik Hubungan Persentase Peningkatan Radang dan Penurunan Ambang Nyeri Tekan Sesudah Radang Maksimal pada Kelompok Kontrol Sakit

Keterangan: Grafik ini adalah hasil analisis regresi untuk mengetahui hubungan persentase penurunan ambang nyeri (x) dengan persentase peningkatan radang (y) sesudah kelompok kontrol sakit mengalami radang maksimal sehingga diperoleh persamaan matematika $y=2,120 x=14,91$ dan koefisien determinasi $\left(R^{2}\right)=0,965$ 
Persentase inhibisi radang tiap kelompok perlakuan dapat dilihat pada Tabel 3, sedangkan persentase inhibisi nyeri dapat dilihat pada Tabel 4.

Tabel 3 Persentase Inhibisi Radang Karagenan Kaki Tikus

\begin{tabular}{|c|c|c|c|c|c|c|c|c|}
\hline \multirow{2}{*}{ Kelompok } & \multicolumn{6}{|c|}{ AUC pada waktu pengamatan } & \multirow{2}{*}{ Total AUC } & \multirow{2}{*}{$\begin{array}{l}\text { \% inhibisi } \\
\text { radang }\end{array}$} \\
\hline & T0-T1 & T1-T2 & T2-T3 & T3-T4 & T4-T5 & T5-T6 & & \\
\hline Kontrol sakit & $\begin{array}{c}0,01088 \pm \\
0,00063\end{array}$ & $\begin{array}{c}0,00050 \pm \\
0,00071\end{array}$ & $\begin{array}{c}0,00075 \pm \\
0,00050\end{array}$ & $\begin{array}{c}0,00025 \pm \\
0,00029\end{array}$ & $\begin{array}{c}-0,00037 \pm \\
0,00025\end{array}$ & $\begin{array}{c}-0,00175 \pm \\
0,00096\end{array}$ & $\begin{array}{c}0,01025 \pm \\
0,00333\end{array}$ & 0 \\
\hline $\begin{array}{c}\text { Asam mefenamat } \\
50 \mathrm{mg} / \mathrm{kgBB} \\
\text { tikus }\end{array}$ & $\begin{array}{c}0,00488 \pm \\
0,00103\end{array}$ & $\begin{array}{c}0,00119 \pm \\
0,00103\end{array}$ & $\begin{array}{c}0,00006 \pm \\
0,00136\end{array}$ & 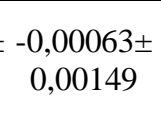 & $\begin{array}{c}-0,00050 \pm \\
0,00135\end{array}$ & $\begin{array}{c}-0,00075 \pm \\
0,00126\end{array}$ & $\begin{array}{c}0,00425 \pm \\
0,00752\end{array}$ & $58,53 \%$ \\
\hline $\begin{array}{c}\text { Akupunktur } \\
\text { sebelum induksi }\end{array}$ & $\begin{array}{c}0,00250 \pm \\
0,00071\end{array}$ & $\begin{array}{c}0,00275 \pm \\
0,00132\end{array}$ & $\begin{array}{c}- \\
0,00050 \pm \\
0,00091\end{array}$ & $=\begin{array}{c}-0,00125 \pm \\
0,00096\end{array}$ & $\begin{array}{c}-0,00088 \pm \\
0,00025\end{array}$ & $\begin{array}{c}-0,00037 \pm \\
0,00048\end{array}$ & $\begin{array}{c}0,00225 \pm \\
0,00463\end{array}$ & $78,048 \%$ \\
\hline $\begin{array}{c}\text { Akupunktur } \\
\text { sesudah induksi }\end{array}$ & $\begin{array}{c}0,01013 \pm \\
0,00131\end{array}$ & $\begin{array}{c}0,00125 \pm \\
0,00096\end{array}$ & $\begin{array}{c}0,00100 \pm \\
0,00108\end{array}$ & $\begin{array}{c}-0,00050 \pm \\
0,00108\end{array}$ & $\begin{array}{c}-0,00038 \pm \\
0,00075\end{array}$ & $\begin{array}{c}-0,00087 \pm \\
0,00063\end{array}$ & $\begin{array}{c}0,01063 \pm \\
0,00581\end{array}$ & $3,65 \%$ \\
\hline $\begin{array}{c}\text { Akupunktur } \\
\text { sebelum induksi- } \\
\text { asam mefenamat }\end{array}$ & $\begin{array}{c}0,00563 \pm \\
0,00063\end{array}$ & $\begin{array}{c}0,00238 \pm \\
0,00075\end{array}$ & $\begin{array}{c}0,00088 \pm \\
0,00085\end{array}$ & $=\begin{array}{c}-0,00050 \pm \\
0,00041\end{array}$ & $\begin{array}{c}-0,00125 \pm \\
0,00029\end{array}$ & $\begin{array}{c}-0,00100 \pm \\
0,00041\end{array}$ & $\begin{array}{c}0,00613 \pm \\
0,00334\end{array}$ & $40,24 \%$ \\
\hline $\begin{array}{c}\text { Akupunktur } \\
\text { sesudah induksi- } \\
\text { asam mefenamat }\end{array}$ & $\begin{array}{c}0,00838 \pm \\
0,00118\end{array}$ & $\begin{array}{c}0,00075 \pm \\
0,00119\end{array}$ & $\begin{array}{c}- \\
0,00037 \pm \\
0,00025\end{array}$ & $=\begin{array}{l}-0,00013 \pm \\
0,00075\end{array}$ & $\begin{array}{c}-0,00113 \pm \\
0,00025\end{array}$ & $\begin{array}{c}-0,00125 \pm \\
0,00155\end{array}$ & $\begin{array}{c}0,00625 \pm \\
0,00518\end{array}$ & $39,02 \%$ \\
\hline
\end{tabular}

Tabel 4 Persentase Inhibisi Nyeri Radang Karagenan Kaki Tikus

\begin{tabular}{|c|c|c|c|c|c|c|c|c|}
\hline \multirow{2}{*}{ Kelompok } & \multicolumn{6}{|c|}{ AUC pada waktu pengamatan } & \multirow{2}{*}{ Total AUC } & \multirow{2}{*}{$\begin{array}{c}\% \text { inhibis } \\
\text { nyeri }\end{array}$} \\
\hline & T0-T1 & $\mathrm{T} 1-\mathrm{T} 2$ & $\mathrm{~T} 2-\mathrm{T} 3$ & T3-T4 & T4-T5 & T5-T6 & & \\
\hline Kontrol sakit & $\begin{array}{c}0,437 \pm \\
0,165 \\
\end{array}$ & $\begin{array}{c}0,793 \pm \\
0,180 \\
\end{array}$ & $\begin{array}{c}0,812 \pm \\
0,047\end{array}$ & $\begin{array}{c}0,743 \pm \\
0,178 \\
\end{array}$ & $\begin{array}{c}0,806 \pm \\
0,144 \\
\end{array}$ & $\begin{array}{c}0,875 \pm \\
0,045 \\
\end{array}$ & $\begin{array}{c}4,468 \pm \\
0,762\end{array}$ & 0 \\
\hline $\begin{array}{l}\text { Asam mefenamat } \\
50 \mathrm{mg} / \mathrm{kgBB} \text { tikus }\end{array}$ & $\begin{array}{c}1,037 \pm \\
0,217\end{array}$ & $\begin{array}{c}0,925 \pm \\
0,174\end{array}$ & $\begin{array}{c}0,9375 \pm \\
0,062\end{array}$ & $\begin{array}{c}0,925 \pm \\
0,064\end{array}$ & $\begin{array}{l}0,981 \pm \\
0,055\end{array}$ & $\begin{array}{c}0,962 \pm \\
0,110\end{array}$ & $\begin{array}{c}5,768 \pm \\
0,685\end{array}$ & $29,09 \%$ \\
\hline $\begin{array}{c}\text { Akupunktur } \\
\text { sebelum induksi }\end{array}$ & $\begin{array}{c}1,075 \pm \\
0,366\end{array}$ & $\begin{array}{c}0,712 \pm \\
0,125\end{array}$ & $\begin{array}{c}0,818 \pm \\
0,159\end{array}$ & $\begin{array}{c}0,862 \pm \\
0,170\end{array}$ & $\begin{array}{c}0,975 \pm \\
0,165\end{array}$ & $\begin{array}{c}1,056 \pm \\
0,196\end{array}$ & $\begin{array}{c}5,500 \pm \\
1,183\end{array}$ & $23,07 \%$ \\
\hline $\begin{array}{c}\text { Akupunktur } \\
\text { sesudah induksi }\end{array}$ & $\begin{array}{c}0,406 \pm \\
0,132\end{array}$ & $\begin{array}{c}0,750 \pm \\
0,163\end{array}$ & $\begin{array}{c}0,875 \pm \\
0,221\end{array}$ & $\begin{array}{c}0,887 \pm \\
0,193\end{array}$ & $\begin{array}{l}1,175 \pm \\
0,306\end{array}$ & $\begin{array}{c}1,062 \pm \\
0,125\end{array}$ & $\begin{array}{c}5,156 \pm \\
1,142\end{array}$ & $15,30 \%$ \\
\hline $\begin{array}{c}\text { Akupunktur } \\
\text { sebelum induksi- } \\
\text { asam mefenamat }\end{array}$ & $\begin{array}{c}0,725 \pm \\
0,155\end{array}$ & $\begin{array}{c}0,706 \pm \\
0,074\end{array}$ & $\begin{array}{c}0,787 \pm \\
0,075\end{array}$ & $\begin{array}{c}0,918 \pm \\
0,143\end{array}$ & $\begin{array}{c}0,843 \pm \\
0,112\end{array}$ & $\begin{array}{c}0,887 \pm \\
0,043\end{array}$ & $\begin{array}{c}4,868 \pm \\
0,604\end{array}$ & $8,95 \%$ \\
\hline $\begin{array}{c}\text { Akupunktur } \\
\text { sesudah induksi- } \\
\text { asam mefenamat }\end{array}$ & $\begin{array}{c}0,512 \pm \\
0,110\end{array}$ & $\begin{array}{c}0,887 \pm \\
0,103\end{array}$ & $\begin{array}{c}0,700 \pm \\
0,129\end{array}$ & $\begin{array}{c}0,900 \pm \\
0,122\end{array}$ & $\begin{array}{c}0,8125 \pm \\
0,094\end{array}$ & $\begin{array}{c}1,000 \pm \\
0,212\end{array}$ & $\begin{array}{c}4,812 \pm \\
0,772\end{array}$ & $7,69 \%$ \\
\hline
\end{tabular}




\section{Research Article}

\section{Pembahasan}

Rumus persentase penurunan ambang nyeri berbeda dengan rumus persentase peningkatan radang karena pada pengukuran ambang nyeri tekan, semakin kecil nilai nyeri tekan, semakin rendah kemampuan terapi pengobatan nyeri. Agar diperoleh hasil kurva yang searah, maka perumusan pada ambang nyeri diberi tanda minus dan ditulis dengan persen penurunan ambang nyeri.

Hubungan persentase peningkatan volume radang dan penurunan ambang nyeri pada kelompok kontrol sakit yang dapat terlihat pada Gambar 2 dan Gambar 3 menjelaskan bahwa nilai ambang nyeri menjadi searah dengan volume radang dimulai sejak T4 sampai T6 (setelah radang maksimal), yang berarti nilai ambang nyeri dapat menggambarkan nilai volume radang pada radang karagenan kaki tikus di waktu tersebut.. Hal ini kemungkinan karena pelepasan prostaglandin sebagai mediator nyeri pada proses radang karagenan kaki tikus terjadi pada T3T5 dengan puncak T4. Mekanisme inflamasi pada karagenan terjadi dalam dua tahap. Tahap pertama terjadi pada 60 menit pertama setelah suntikan karagenan dan berkurang setelah dua jam. Pada tahap ini terjadi aktivasi makrofag disertai pelepasan mediator seperti histamin dan serotonin, kerusakan organel sel endotel sitoplasma pembuluh darah, serta ekspresi IL-1 dari sel endotel sitoplasma yang rusak. Pada tahap awal ini juga terjadi pelepasan substansi P, Tahap kedua terjadi pada akhir tahap pertama dan bertahan pada jam ketiga sampai jam kelima, Pada tahap ini terjadi pelepasan bradikinin dan prostaglandin sebagai mediator nyeri. ${ }^{7}$

Sesuai dengan mekanisme terjadinya radang, dolor (nyeri) merupakan tanda inflamasi yang muncul setelah gejala calor (panas), rubor (kemerahan), dan tumor (pembengkakan), Nyeri terjadi karena penekanan jaringan akibat pembengkakan serta adanya mediator peradangan akut, diantaranya prostaglandin dan bradikinin yang akan merangsang nosiseptor dan menimbulkan impuls nosiseptif. Hal ini juga dapat menjelaskan hubungan persentase peningkatan radang dan persentase penurunan ambang nyeri pada Gambar 3 dan Gambar $4 .^{8}$

Berdasarkan perhitungan dan analisis statistik, diperoleh hasil bahwa asam mefenamat $50 \mathrm{mg} / \mathrm{kg}$ BB dapat menurunkan volume radang kaki tikus secara bermakna $(\mathrm{p}<0,05)$ terhadap kelompok kontrol sakit pada T1 sampai T6 dengan persentase peningkatan volume radang masing masing sebesar 27,92\%, 34,83\%, 35,11\%, 31,4\%, 28,64\% dan 24,27\%, Asam mefenamat juga dapat meningkatkan ambang nyeri tekan secara bermakna $(\mathrm{p}<0,05)$ terhadap kelompok sakit pada T1 sampai T4 dengan persentase penurunan ambang nyeri masing-masing sebesar 0,73\%,7\%,9,33\%, dan 11,15\% namun tidak bermakna pada T5 dan T6 (p>0,05) dengan persentase penurunan ambang nyeri sebesar $28,64 \%$ dan $24,27 \%$. Hal ini menjelaskan 


\section{Research Article}

bahwa asam mefenamat yang merupakan golongan NSAID terbukti berkhasiat sebagai antiinflamasi dan analgetika dengan mekanisme menghambat prostaglandin melalui penghambatan terhadap enzim siklooksigenase sehingga dapat digunakan sebagai obat pembanding.

Akupunktur sebelum induksi dapat menurunkan volume radang secara bermakna $(\mathrm{p}<0,05)$ terhadap kelompok kontrol sakit pada T1 sampai T6 dengan persentase peningkatan volume radang masing masing sebesar 14,08\%, 29,07\%, 26,9\%, 19,8\%, 14,9\% dan 12,85\%, Akupunktur sebelum induksi juga dapat meningkatkan ambang nyeri secara bermakna $(p<0,05)$ terhadap kelompok sakit pada T1 dengan persentase penurunan ambang nyeri sebesar 1,91\% dan tidak bermakna terhadap kelompok sakit pada T2 sampai T6 dengan persentase penurunan ambang nyeri sebesar 19,40\%, 23,02\%, 23,08\%, 18,26\%, dan 11,91\%.

Akupunktur sesudah induksi tidak berbeda bermakna $(\mathrm{p}>0,05)$ dalam menurunkan volume radang terhadap kelompok kontrol sakit pada T1 hingga T6 dengan persentase peningkatan volume radang sebesar 57,16\%, 64,18\%, 69,71\%, 67,01\%, 64,86\%, 59,94\%, Akupunktur sesudah induksi juga tidak berbeda bermakna dalam meningkatkan ambang nyeri terhadap kelompok kontrol sakit pada T1 sampai T4 dengan persentase penurunan ambang nyeri $30,62 \%, 31,24 \%, 25,87 \%$, dan $21,22 \%$, namun kemudian terdapat perbedaan yang bermakna $(\mathrm{p}<0,05)$ pada T5 sampai T6 masing masing sebesar 6,33\% dan 4,54\%.

Potensi terapi akupunktur sesudah induksi (nilai inhibisi radang 3,65\%; nilai inhibisi nyeri $15,30 \%$ ) lebih kecil dibandingkan dengan potensi terapi akupunktur sebelum induksi (nilai inhibisi radang 78,04\%; nilai inhibisi nyeri 23,07\%). Perbedaan potensi terapi akupunktur sebelum dan sesudah induksi ini menjelaskan bahwa terjadi respon yang berbeda terhadap akupunktur pada hewan uji normal dan hewan uji sakit. Salah satu mekanisme akupunktur dalam menurunkan respon inflamasi adalah menekan sitokin proinflamasi, neuropeptida proinflamasi dan neurotropin juga meningkatkan sitokin Th1 seperti IL-2 dan IFN $\gamma$. Pada pemberian akupunktur sebelum induksi, sitokin ini telah disiapkan sesaat setelah pemberian akupunktur sehingga saat induksi dilakukan penghambatan inflamasi terjadi lebih cepat dan bermakna. Berbeda halnya dengan pemberian akupunktur sesudah induksi, saat tikus telah mengalami peradangan sebelumnya. ${ }^{9,10}$

Potensi inhibisi radang dari kelompok akupunktur sebelum induksi lebih besar daripada kelompok asam mefenamat $(78,04 \%$ vs 58,53\%), tetapi potensi inhibisi nyeri kelompok akupunktur sebelum induksi lebih kecil namun tidak bermakna terhadap kelompok asam mefenamat $(23,07 \%$ vs $29,09 \%)$ pada radang karagenan kaki tikus. Hal ini sesuai dengan 


\section{Research Article}

penelitian yang dipublikasikan dalam The European Journal of Obstetrics, Gynaecology and Reproductive Biology yang menyatakan bahwa akupunktur memiliki efektivitas yang sama atau tidak berbeda bermakna dengan NSAID dalam menghilangkan nyeri akut ${ }^{11}$

Kombinasi akupunktur sebelum induksi - asam mefenamat menunjukkan nilai yang lebih kecil bermakna $(\mathrm{p}<0,05)$ dalam menurunkan volume radang dibandingkan dengan kelompok terapi tunggal asam mefenamat maupun akupunktur sebelum induksi pada T1 hingga T6 dengan persentase peningkatan volume radang sebesar 31,26\%, 44,46\%, 49,30\%, $46,52 \%, 39,57 \%$, dan $34,05 \%$. Demikian pula dalam meningkatkan ambang nyeri dibandingkan kelompok asam mefenamat pada T2 dan T3 dengan persentase penurunan ambang nyeri $22,42 \%$ dan $24,46 \%$, namun tidak berbeda secara bermakna ( $>0,05)$ pada T1, T4, T5 dan T6 dengan persentase penurunan ambang nyeri 14,77\%, 19,01\%, 19,17\%, dan 17,20\%. Kombinasi akupunktur sebelum induksi - asam mefenamat tidak berbeda $(\mathrm{p}>0,05)$ secara bermakna dalam meningkatkan ambang nyeri dibandingkan dengan kelompok akupunktur sebelum induksi.

Potensi terapi kombinasi akupunktur sebelum induksi - asam mefenamat (nilai inhibisi radang 40,24\%; nilai inhibisi nyeri 8,95\%) yang lebih kecil daripada terapi tunggal asam mefenamat (nilai inhibisi radang 58,53\%; nilai inhibisi nyeri 29,09\%) dan terapi tunggal akupunktur sebelum induksi (nilai inhibisi radang 78,04\%; nilai inhibisi nyeri 23,07\%) dapat dijelaskan melalui perbedaan mekanisme kerja akupunktur dan NSAID (asam mefenamat). Secara lokal, penjaruman dapat menyebabkan mikrotrauma sehingga jaringan melepaskan mediatornya, salah satunya prostaglandin yang bekerja untuk memperbaiki kerusakan jaringan, sedangkan NSAID bekerja dengan menghambat mediator peradangan prostaglandin. Akupunktur juga secara bermakna meningkatkan leukosit dan neutrofil sementara NSAID menghambat efek ini. Penghambatan ini dapat menghambat kerja akupunktur dalam memperbaiki kerusakan jaringan. Secara sentral, akupunktur dapat meningkatkan pelepasan kortisol, suatu hormon dengan efek antiinflamasi, sedangkan NSAID dapat menghambat pelepasan kortisol. ${ }^{9,12-14}$

\section{Simpulan}

Asam mefenamat berpengaruh menurunkan efektivitas akupunktur dalam mengatasi nyeri radang. Berdasarkan hasil penelitian uji antiinflamasi dan analgesik dengan akupunktur ini, asam mefenamat dan kombinasinya yang dilakukan secara bersamaan dengan menggunakan metode radang karagenan kaki tikus serta diukur dengan alat pletismometer dan dolorimeter menyebabkan penurunan efektivitas akupunktur dalam mengatasi nyeri radang karagenan kaki 


\section{Research Article}

tikus sehingga secara klinis perlu diperhatikan pemberian obat-obat anti inflamasi non steroid bersamaan dengan akupunktur untuk pasien dengan keluhan nyeri radang.

\section{Daftar Pustaka}

1. Mitchell RN, Cotran RS. Acute and chronic inflammation. In Robbin SL, Kumar V. Basic Pathology. Philadelphia: Elsevier Saunders; 2003. p. 33-59.

2. Janeway, Charles A, Travers P, Walport M, Shlomchik M. Immunobiology. New York: Garland Science; 2001.

3. Wilmana PF, Gan S. Analgesik-antipiretik antiInflamasi nonsteroid dan obat gangguan sendi lainnya.In Farmakologi dan Terapi Edisi 5. Jakarta: Departemen Farmakologi dan Terapeutik FK UI; 2007. h. 237-9.

4. Katz JA, Berry PH, Covington EC, Dahl JL, Miaskowski C. Pain current understanding of assessment, management, and treatments. National Pharmaceutical Council Inc; 2001.

5. Katzung BG, Farmakologi dasar dan klinik. Jakarta: Salemba Merdeka; 2004.

6. Audette JF, Ryan AH, The role of acupuncture in pain management, Phys Med Rehabil Clin, 2004;15:749-72.

7. Suralkar AA, Prashant SS, Mahesh MG, Deshpande AD. In vivo animal models for evaluation of antiinflammatory activity. J Adv Med Pharm Sci. 2(2):67-73.

8. Price SA, Wilson LM, Patofisiologi konsep klinik proses-proses penyakit edisi 4. Jakarta:EGC; 2005.

9. Lin JG, Chen WL. Acupuncture analgesia, a review of its mehanisms of actions. Am J Chin Med. 2008; 36(4):635-45.

10. Muthmainah. Pengaruh akupunktur terhadap jumlah eosinofil bronkiolus tikus putih model asma. Fakultas Kedokteran Universitas Sebelas Maret; 2011.

11. Kiran G, Gumusalan Y, Ekerbicer HC, Kiran H, Coskun A, Arikan DC, A randomized pilot study of acupuncture treatment for primary dysmenorrheal. Eu J Obs Gyn Rep Biol. 2013;169(2):292-5.

12. Zijlstra FJ, Lange IB, Huygen F, Klein J. Anti-inflammatory actions of acupuncture. Mediators Inflamm. Francis Health Sci. 2003;12(2):59-69.

13. Rivas VJF, Barrera EE, Fregoso PM, The effect of acupuncture on leukocyte levels in peripheral blood is modified by aspirin. Proc West Pharmacol Soc. 2009;52:61-2.

14. Akingbola OA, Singh D, Kleinman JA, Friberg EM, Functional adrenal insufficiency complicating an overdose of naproxen and ibuprofen. Clin Ped Journ. 2015;54(1):76-8.

15. Wu MT, Shaw LH, Wu YT, Tsai TH, Interaction of acupuncture and electroacupuncture on the pharmacokinetics of aspirin and the effect of brain blood flow in rats. Evid Based Complement Alternat Med. 2013;6(70):85-8. 